\section{Problems of British science}

SIR - One of the major points not addressed in your Manifesto for British Science (Nature 353, 105; 1991) is that of an adequate career structure for British university academics which, of course, goes wider than science and technology. The small proportion of senior academic (that is, professorial) posts at British universities means that many distinguished academics cannot rise above the normal career lecturer grade. In contrast, in the North American university system, academics are periodically assessed for promotion on merit on an ad personam basis, through the ranks of assistant-, associate- and full-professor, with the latter not necessarily being tied to the headship of a department, as is mostly the case in the United Kingdom. Indeed, the North American system of democratically elected, rotating chairmanships of a department, usually chosen from the ranks of associate- and full-professors, is barely in its infancy in Britain. For better or worse, most UK university departments are run by professors (in the British terminology) elected until the retiring age, whose activities necessarily become dominated by administration.

I believe that the lack of realistic promotion prospects is one of the main reasons why young, promising, suitably qualified British academics seek their fortunes abroad. A high proportion of postdoctoral workers from my own research group have done so with great success over the past 30 years, and would not contemplate returning to the United Kingdom under present conditions. All British university departments are familiar with this situation. The relative lack of promotion prospects, rather than money alone, is one of the main causes of dissatisfaction among British academics, and it is frequently referred to when one visits expatriates working abroad.

In recent years there has been a move - for example in some Earth science departments, after their recent national reorganization - to head-hunt distinguished senior British academics who have deservedly made the grade abroad, by offering them incentives far superior to what they could have expected if they had remained in the United Kingdom in the first place. In my view, it would be more effective if a higher proportion of promising academics had the opportunity of fulfilling their talent and potential in the United Kingdom right from the beginning and throughout their careers.

Some aspects of the British career structure for university academics have clearly outlived their usefulness. It could be that the main reason why this impor- tant problem is rarely addressed by the relevant committees, organizations and institutions within the United Kingdom is that the people in the best position to initiate change - most of whom are well acquainted with the North American system - also have the highest incentive to maintain the status quo.

STEPHEN MOORBATH

Department of Earth Sciences,

University of Oxford,

Oxford OX1 3PR, UK

SIR - At this large Medical Research Council (MRC) unit where I am director of studies, we interview many prospective graduate students and ask them to talk about their honours projects. The standard is impressive and derives from the students having learnt a wide range of skills in completing a 3-6 month laboratory project under an active research worker.

If departments are to take on many more honours students, as they are being encouraged to do, it will not be possible for them all to undertake experimental projects because of a lack of supervisors, laboratory space and equipment. Instead, students will have to produce literature surveys for their honours projects and will thus end up being far less well trained in experimentation than they are now. The net result will be that graduates will leave the universities with little real laboratory experience and, perhaps, diminished enthusiasm for their subject. For the few who intend to do $\mathrm{PhDs}$, this ignorance will only slow their future progress, but, for the majority going into industry, matters are far more serious: companies will have to provide the facilities to teach their new employees the laboratory skills that they have hitherto taken for granted.

Unless extra funds are provided for university staff and laboratories very soon, more honours students in science will mean worse students, irrespective of their ability and of whether they do three- or four- year degrees.

\section{MRC Human Genetics Unit,} JONATHAN BARD

\section{Western General Hospital,}

Crewe Road, Edinburgh EH4 2XU, UK

SIR - Your recent Manifesto for British Science was certainly thought-provoking. However, it was grossly inaccurate in one important element, repeated in your leading article on 19 September (353, $195 ;$ 1991), involving the relationship between the Ministry of Agriculture, Fisheries and Food and the Agricultural and Food Research Council (AFRC). The ministry's contribution to the AFRC's budget is not "virtually zero" and we certainly did not "simply walk away" from our contract with the council. We have a close working relationship, as befits the two largest funders and practitioners of agricultural and food research in the country. And the ministry does continue to fund the council. Last year our commissions with the council came to $£ 45$ million, 30 per cent of its budget. \section{(Chief Sci
riculture, \\ Fisheries and Food, \\ Nobel House, 17 Smith Square, London SW1P 3JR, UK}

SIR - There is discontent with the present method of allocating British research council project grants that seems to run deeper than the grumbling that one might expect from people who think they deserved a grant.

The universities and similar institutions are now engaged in a deadly game of Strip Jack Naked, based in part on research ratings which will determine their access to other funds. Ratings depend in turn on success in obtaining research council grants. The system is intended to approximate to a free market.

But in what free market is a trader obliged to reveal all his sources and ideas to a panel of rival traders? Research applications are placed before referees and committees comprised of representatives of the very institutions that will benefit from the failure of the application.

At the very least, panel members and referees can and do take advantage of reading grant applications for improvement of or downright incorporation into their own applications; as the 'unknowing' of something one has read is impossible, their own publications and research clearly benefit from the sight of rejected applications.

Anonymity and confidentiality meanwhile ensure that referees and panels can make self-interested or more often plainly ignorant or misguided criticisms of applications that they would never dare to put their name to on the open page, and to which the applicants have little access or right of reply.

This set-up is certainly stifling good and original research, and is not improving the atmosphere. It is hard to understand why the relevant authorities contemplate it with such complacency. The importance of 'getting it right' will increase as central research money is increasingly removed from 'dual funding' and transferred to the research councils.

Department of Genetics, J.R.G. TURNER

University of Leeds,

Leeds LS2 9JT, UK 